\title{
Effects of epigeic earthworm (Eisenia fetida) and arbuscular mycorrhizal fungus (Glomus intraradices) on enzyme activities of a sterilized soil-sand mixture and nutrient uptake by maize
}

\author{
Huan Li • Dan Xiang $\cdot$ Chong Wang $\cdot$ Xiaolin Li $\cdot$ Yi Lou
}

Received: 14 December 2011 /Revised: 7 March 2012 / Accepted: 19 March 2012 /Published online: 18 April 2012

(C) Springer-Verlag 2012

\begin{abstract}
A pot experiment was conducted to investigate the effect of epigeic earthworm (Eisenia fetida) and arbuscular mycorrhizal (AM) fungi (Glomus intraradices) on soil enzyme activities and nutrient uptake by maize, which was grown on a mixture of sterilized soil and sand. Maize plants were grown in pots inoculated or not inoculated with AMF, treated or not treated with earthworms. Wheat straw was added as a feed source for earthworms. Mycorrhizal colonization of maize was markedly increased in AM fungi inoculated pots and further increased by addition of epigeic earthworms. AM fungi and epigeic earthworms increased maize shoot and root biomass, respectively. Soil acid phosphatase activity was increased by both earthworms and mycorrhiza, while urease and cellulase activities were only affected by earthworms. Inoculation with AM fungi significantly $(p<0.001)$ increased the activity of soil acid phosphatase but decreased soil available phosphorus (P) and potassium $(\mathrm{K})$ concentrations at harvest. Addition of earthworms alone significantly $(p<0.05)$ increased soil ammonium-N content, but decreased soil available $\mathrm{P}$ and $\mathrm{K}$ contents. AM fungi increased maize shoot weight and root $\mathrm{P}$ content, while earthworms improved $\mathrm{N}, \mathrm{P}$, and $\mathrm{K}$ contents in shoots. AM fungi and earthworm interactively increased maize shoot and root biomass through their regulation
\end{abstract}

Dan Xiang contributed equally.

H. Li $\cdot$ C. Wang $(\triangle) \cdot \mathrm{X}$. Li $\cdot$ Y. Lou

College of Resource and Environmental Science, China

Agricultural University,

Beijing 100193, China

e-mail: wangchong@cau.edu.cn

D. Xiang

Research Center for Eco-Environmental Sciences,

Chinese Academy of Sciences,

Beijing 100085, China of soil enzyme activities and on the content of available soil $\mathrm{N}$, $\mathrm{P}$, and $\mathrm{K}$.

Keywords Soil urease · Soil phosphatase - Soil cellulose · Mycorrhizal colonization · Shoot and root biomass

\section{Introduction}

Interactions between plants and soil organisms are widespread and essential for nutrient uptake by plants (Wurst et al. 2010). Earthworms, arbuscular mycorrhizal fungi (AM fungi), and plant roots are key components of soil biota (Six et al. 2002). AM fungi are symbiotically associated with the roots of two-thirds of terrestrial plant species (Smith and Read 2008). The extraradical mycelium of AM fungi increases nutrient uptake by the root system by extending the exploited soil volume (Tuffen et al. 2002). Earthworms influence plant growth by changing the spatiotemporal availability of $\mathrm{P}, \mathrm{N}$, and $\mathrm{C}$ in their casts and burrow walls (Milleret et al. 2009).

Earthworms and AM fungi have been extensively studied for their interactions in rhizosphere (Eisenhauer et al. 2009; Milleret et al. 2009; Wurst et al. 2004). These organisms belong to different guilds (Bardgett 2005) in soil and can create distinct niches for plants (Wurst et al. 2010). They impact plant growth by complementarily affecting soil nutrient availability. For example, AM fungi can increase soil $\mathrm{P}$ availability and earthworms can promote $\mathrm{N}$ availability (Li et al. 2012; Ortiz-Ceballos et al. 2007; Wurst et al. 2004), but their effect on plant growth depend on the presence of these nutrients in soil (Milleret et al. 2009). While soil fertility has been the focus of research, few studies have been conducted to examine interactive effects of earthworms 
and AM fungi on enzyme activities that play an essential role in soil biochemical transformation, organic residue decomposition, and nutrient cycling (Dilly and Irmler 1998; McLatchey and Reddy 1998).

Soil enzymes originated from soil microorganisms, plant roots, plant debris, and animals. Enzyme activities can be used to monitor changes in soil microbial activity and soil fertility (Parthasarathi and Ranganathan 2000). AM fungi can increase the activity of soil phosphatase (Mar Vázquez et al. 2000), dehydrogenase, urease, acid phosphatase, protease, and B-glucosidase (Caravaca et al. 2004). The presence of earthworms in soil can also affect enzyme activities (Tao et al. 2009) such as protease, phosphatase, $\beta$-glucosidase, invertase, amylase, and cellulase activities (Aira et al. 2005; Parthasarathi and Ranganathan 2000; Zhang et al. 2000). However, information on interactions of AM fungi and earthworms on soil enzyme activities is lacking.

According to their habitat and behavior, earthworms are epigeic (litter inhibiters, e.g. Eisenia fetida), endogeic (vertical burrowers, e.g. Allolobophora chlorotica), or anecic (mineral dwellers, e.g. Lumbricus terrestris) (Römbke et al. 2005). Studies of AM fungi and earthworm interaction have been focused on anecic species (such as L. terrestris L.) (Scheu 2003) or endogeic species (such as Aporrectodea caliginosa S.) (Partsch et al. 2006; Tuffen et al. 2002; Wurst et al. 2004), and little is known about the interaction of epigeic species and AM fungi and their effects on soil properties and plant growth. The objective of this study was to investigate the effects of epigeic species (E. fetida) and AM fungi (Glomus intraradices) on soil enzyme activities and nutrient uptake by maize, which was grown on a mixture of sterilized soil and sand. In order to avoid the effects of indigenous AM fungi and earthworms on enzyme activities and increase soil porosity and permeability, we used a sterilized soil-sand mixture (Hayman and Tavares 1985). Soil filtrate $(0.45-\mu \mathrm{m}$ pore size) was also used to provide similar soil conditions for microbial communities (Calvet et al 1993).

\section{Materials and methods}

\section{Soil and organisms}

Loamy sand soil was obtained from the top 0 - to 20-cm layer of a crop field in Quzhou Experimental Station, China Agricultural University $\left(36.5^{\circ} \mathrm{N}, 115.0^{\circ} \mathrm{E}\right)$. The soil was air-dried, sieved to pass $2.0 \mathrm{~mm}$ and autoclaved at $121{ }^{\circ} \mathrm{C}$ for $2 \mathrm{~h}$. Each kilogram of soil contained $1.8 \mathrm{~g}$ total $\mathrm{N}, 13 \mathrm{~g}$ organic $\mathrm{C}$, $7.72 \mathrm{mg}$ available $\mathrm{P}$ (Olsen-P), and $33.6 \mathrm{mg}$ available $\mathrm{K}$ $\left(\mathrm{NH}_{4} \mathrm{OAc}-\mathrm{K}\right) \cdot \mathrm{pH}\left(\mathrm{H}_{2} \mathrm{O}\right.$, soil $\left.2.5: 1, \mathrm{v} / \mathrm{v}\right)$ was 8.44 . Soil and river sand were sieved $(<2 \mathrm{~mm})$ and sterilized by autoclaving at $121{ }^{\circ} \mathrm{C}$ for $2 \mathrm{~h}$. After drying at room temperature, the soil and river sand were mixed at a ratio of 1:1 (v/v).
Earthworms (E. fetida) obtained from the same field where the soil was collected were washed with distilled water and kept in sterilized glass vessels for $24 \mathrm{~h}$ to eliminate naturally occurring mycorrhizal propagules on their surfaces or in their gut contents. An AM ( $G$. intraradices Schenck and Smith) inoculum (BEG141) was propagated on maize and white clover host plants in a growth chamber maintained at $30 / 18{ }^{\circ} \mathrm{C}, 16 / 8 \mathrm{~h} \mathrm{light/dark}$ rotation and 50 $75 \%$ relative humidity.

\section{Experimental design and inoculation}

A completely randomized block design with a $2 \times 2$ factorial arrangement of treatments was utilized. The factors were AM fungi and earthworms, each having two levels (AM fungi inoculated or not inoculated; earthworms added or not added). Therefore, we had the following four treatments: soil-sand without earthworm and mycorrhizae (CK), soil-sand with earthworm addition (E), soil-sand with mycorrhizal addition (AM), and soil-sand with both earthworms and mycorrhizae $(\mathrm{AM}+\mathrm{E})$. The sterilized soil-sand mixture of the CK and $\mathrm{E}$ treatments were treated with sterilized mycorrhizae inoculum (see below). Each treatment was replicated four times.

Plastic pots $(16 \mathrm{~cm}$ in diameter, $14 \mathrm{~cm}$ in height) were filled with $1.5 \mathrm{~kg}$ sieved $(<2 \mathrm{~mm})$ and sterilized soil-sand mixture that was mixed with $8 \mathrm{~g}$ oven-dried wheat straw. A $1-\mathrm{mm}$ mesh with a $3-\mathrm{cm}$ diameter hole in the center was placed at the top of the pot to prevent the escape of inoculated earthworms and to allow plant growth. Living or sterilized mycorrhiza innoculum was placed about $2 \mathrm{~cm}$ under the soil surface at $35 \mathrm{~g} \mathrm{~kg}^{-1}$. The filtrate $(0.45 \mu \mathrm{m}$ pore size) and sterilized mycorrhiza were used to provide similar nutrients of the live inoculum to soil (Calvet et al. 1993). Three adult earthworms of E. fetida with similar fresh weight were added to the appropriate pots when the third leaf emerged.

Maize seeds (Nong Da 108) were surface sterilized with a $10 \%(\mathrm{v} / \mathrm{v})$ solution of $\mathrm{H}_{2} \mathrm{O}_{2}$ for $10 \mathrm{~min}$, rinsed thoroughly with deionized water, placed on autoclaved filter paper soaked with sterile distilled water, and incubated at $25{ }^{\circ} \mathrm{C}$ for $24 \mathrm{~h}$. Two seeds were planted in each plot. After the emergence of the third leaf, only one plant was kept. Each kilogram of the soil-sand mixture was fertilized with a solution containing: $200 \mathrm{mg} \mathrm{N}\left(\mathrm{NH}_{4} \mathrm{NO}_{3}\right), 50 \mathrm{mg} \mathrm{P}$ $\left(\mathrm{KH}_{2} \mathrm{PO}_{4}\right), 200 \mathrm{mg} \mathrm{K}\left(\mathrm{K}_{2} \mathrm{SO}_{4}\right), 100 \mathrm{mg} \mathrm{Mg}\left(\mathrm{MgSO}_{4}\right.$ $\left.0.7 \mathrm{H}_{2} \mathrm{O}\right), 5 \mathrm{mg} \mathrm{Zn}\left(\mathrm{ZnSO}_{4} 0.7 \mathrm{H}_{2} \mathrm{O}\right), 5 \mathrm{mg} \mathrm{Mn}\left(\mathrm{MnSO}_{4}\right.$ $0.7 \mathrm{H}_{2} \mathrm{O}$ ), and $5 \mathrm{mg} \mathrm{Cu}\left(\mathrm{CuSO}_{4} 0.5 \mathrm{H}_{2} \mathrm{O}\right)$ (Zhang et al. 2008). Seedlings were grown from March to May in a greenhouse at China Agricultural University, Beijing, with $16 \mathrm{~h} / 8 \mathrm{~h}$ (light/dark) photoperiods, $25^{\circ} \mathrm{C} / 16{ }^{\circ} \mathrm{C}$ (day/night), and $42 \%$ relative humidity. All pots were arranged according to the experimental design and irrigated daily with deionized water. 
Sampling and analysis

The experiment was carried out from April 4th to June 14th. Shoot, root, and rhizosphere samples were collected at the end of the experiment. Maize shoots were dried $\left(65{ }^{\circ} \mathrm{C}\right.$, $48 \mathrm{~h}$ ) and weighed. Roots were gently removed from soil by handpicking and sieving $(2 \mathrm{~mm})$; then they were washed, dried $\left(65^{\circ} \mathrm{C}, 48 \mathrm{~h}\right)$, and weighed. AMF colonization was determined on 30 random pieces of each root sample at $250 \times$ magnification using a modified line intersect method; $1 \mathrm{~g}$ roots was cut by $1-\mathrm{cm}$ root pieces, which were cleared in $10 \% \mathrm{KOH}$, acidified with $1 \% \mathrm{HCl}$ and stained with $0.05 \%$ Trypan blue in lactoglycerol (McGonigle et al. 1990). Hyphal length density (HLD) was determined using the modified procedure by Jakobsen et al. (1992). Briefly, 4-g rhizosphere soil samples (three replicates in each pot) were dispersed in a sodium hexameta phosphate solution $\left(35 \mathrm{gl}^{-1}\right)$ and shaken for $30 \mathrm{~s}$ (end-over-end). After $30 \mathrm{~min}$, the suspension was decanted quantitatively through a $40-\mu \mathrm{m}$ sieve. Retained hyphae, roots, and organic matter were transferred with $200 \mathrm{ml}$ of deionized water into a $250-\mathrm{ml}$ flask. The contents were shaken vigorously by hand for $5 \mathrm{~s}$. After $1 \mathrm{~min}, 4 \times 1 \mathrm{ml}$ aliquots (10-s interval) were pipetted onto Millipore RAWG02500 membranes (Millipore, Bedford, MA, USA). The filter was stained in $0.05 \%$ Trypan blue. HLD was estimated with a gridline intersect method at 250× magnification (Newman 1966).

Dried roots and shoots were digested with mixed $\mathrm{H}_{2} \mathrm{SO}_{4}$ and $\mathrm{H}_{2} \mathrm{O}_{2}(5: 2, \mathrm{v} / \mathrm{v})$. The digest was analyzed for $\mathrm{N}$ with the Kjeldahl method (Axmann et al. 1990), for P using the molybdate blue colorimetric procedure (Murphy and Riley 1962), and for K by flame photometry (Jones and Case 1990). Ammonium was extracted from the soil-sand mixture with $2 \mathrm{M} \mathrm{KCl}$ and determined according to Keeney and Nelson (1982), available P was extracted with $0.5 \mathrm{~mol} \mathrm{l}^{-1}$ $\mathrm{NaHCO}_{3}$ and determined according to Olsen et al. (1954), exchangeable $\mathrm{K}$ was extracted with $\mathrm{N}$ ammonium acetate and determined according to Metson (1956), and organic $\mathrm{C}$ (SOC) was determined by the $\mathrm{K}_{2} \mathrm{Cr}_{2} \mathrm{O}_{7}$ colorimetric oxidization method by Walkley (1947).

Enzyme assays of the sterilized soil-sand mixture

Urease activity was determined as proposed by Kandeler and Gerber (1988). Soil-sand mixture (10 g) was treated with $10 \mathrm{ml}$ urea $(10 \%, \mathrm{w} / \mathrm{v}), 20 \mathrm{ml}$ citrate buffer $(1 \mathrm{M}, \mathrm{pH} 6.7)$, and $1.5 \mathrm{ml}$ methylbenzene and kept at room temperature for $15 \mathrm{~min}$. The sample was then incubated at $37{ }^{\circ} \mathrm{C}$ for $24 \mathrm{~h}$ under shaking. The solution was filtered, and about $1.0 \mathrm{ml}$ of the filtrate was mixed with $10 \mathrm{ml}$ distilled water, $4 \mathrm{ml}$ sodium phenolate hydroxide, and $3.0 \mathrm{ml}$ sodium hypochlorite, and the optical density was determined $20 \mathrm{~min}$ later by a UV-2450 Spectrophotometer at $578 \mathrm{~nm}$. Urease activity was expressed in milligram of $\mathrm{NH}_{4}{ }^{+}-\mathrm{N}$ per gram of dry soil released in $24 \mathrm{~h}$.
Acid ( $\mathrm{pH}$ 6.5) phosphatase activity was determined according to the procedure of Tabatabai (1982) with minor modifications. Four milliliters of a modified universal buffer (MUB, $\mathrm{pH} 6.5$ ) and $1 \mathrm{ml} 25-\mathrm{mM}$ sodium p-nitrophenyl phosphate in MUB were added to $1.0 \mathrm{~g}$ soil and then incubated at $37^{\circ} \mathrm{C}$. After $60 \mathrm{~min}$, the reaction was stopped by adding $4 \mathrm{ml}$ $0.5-\mathrm{M} \mathrm{NaOH}$, and the sample was kept at room temperature for $20 \mathrm{~min}$. The optical density of the solution was determined at $420 \mathrm{~nm}$ and by using $1 \%$ p-nitrophenol as the standard.

Cellulase activity was determined as reported by Mandels et al. (1976). Briefly, $1 \mathrm{ml} 50-\mathrm{mM} \mathrm{pH} 4.8$ citrate buffer, $1 \mathrm{ml}$ filtered solution, $0.5 \mathrm{ml}$ toluene, and a filter paper strip were incubated at $50{ }^{\circ} \mathrm{C}$ for $24 \mathrm{~h}$. Reducing sugar concentration was estimated by the dinitrosalicylic acid method (Miller 1969). Glucose was used as the standard for the analysis.

\section{Statistical analysis}

Analysis of variance was carried out using the SPSS software, version 10.0 (SPSS Institute, Inc., Cary, NC, USA). Duncan's multiple range or Fisher's LSD was used to show significant differences between treatment means at $p<5 \%$, and correlation between the measured parameters were also carried out. Relationships between treatments were tested by Pearson's correlation analyses. The redundancy analysis (RDA) used the Canoco version 4.5 software package. Significance of the first and of all ordinations axes was calculated by the Monte Carlo permutation test.

\section{Results}

By the end of the experiment, no colonization of roots was found in the CK or E treatments. The AM treatment significantly enhanced colonization and all other mycorrhizal parameters $(p<0.001$, Table 1$)$. Adding earthworms to AM fungi significantly $(p<0.05)$ increased maize root colonization rate, hyphae frequency, and HLD.

Compared to the CK treatment, AM significantly increased acid phosphatase activity of the sterilized soil-sand mixture ( $p$ $<0.05$ ) but had no effect on urease and cellulase activities (Table 2). Addition of earthworm alone or in combination with AM fungi increased urease, acid phosphatase, and cellulase activities when compared to the CK treatment $(p<0.05)$. Incubation with AM fungi alone increased acid phosphatase activity of the sterilized soil-sand mixture compared to adding earthworms alone but decreased cellulase activity $(p<0.05)$. Addition of both AM fungi and earthworms resulted in the greatest acid phosphatase activity. The RDA analysis showed that a relationship existed between AM fungi and earthworms and enzyme activities (Fig. 1a). Acid phosphatase activity was positively affected by the presence of both earthworms and 
Table 1 Root colonization rate, hyphal length, and frequency of vesicle, arbuscular, and hyphae of mycorrhized and nonmycorrhized plants inoculated with or without earthworms

\begin{tabular}{|c|c|c|c|c|c|}
\hline $\begin{array}{l}\text { Inoculation } \\
\text { treatment }^{1}\end{array}$ & $\begin{array}{l}\text { Root colonization rate } \\
(\%)\end{array}$ & $\begin{array}{l}\text { Vesicle frequency } \\
(\%)\end{array}$ & $\begin{array}{l}\text { Arbuscular frequency } \\
(\%)\end{array}$ & $\begin{array}{l}\text { Hyphae frequency } \\
(\%)\end{array}$ & $\begin{array}{l}\text { Hyphal length density } \\
\left(\mathrm{g} \mathrm{m}^{-1}\right)\end{array}$ \\
\hline $\mathrm{CK}$ & - & - & - & - & - \\
\hline $\mathrm{AM}$ & $64 \pm 1 \mathrm{a}$ & $15 \pm 2 \mathrm{a}$ & $40 \pm 5 \mathrm{a}$ & $57 \pm 1 \mathrm{a}$ & $2.0 \pm 0.3 \mathrm{a}$ \\
\hline $\mathrm{E}$ & - & - & - & - & - \\
\hline $\mathrm{AM}+\mathrm{E}$ & $71 \pm 2 b$ & $15 \pm 2 \mathrm{a}$ & $43 \pm 3 a$ & $66 \pm 2 b$ & $2.6 \pm 0.2 b$ \\
\hline \multicolumn{6}{|l|}{$\begin{array}{l}\text { Significance }{ }^{a} \text { due } \\
\text { to }\end{array}$} \\
\hline AM inoculation & $* * *$ & $* * *$ & $* * *$ & $* * *$ & $* * *$ \\
\hline $\begin{array}{l}\mathrm{AM} * \mathrm{E} \\
\text { interaction }\end{array}$ & $*$ & NS & NS & $* *$ & $* * *$ \\
\hline
\end{tabular}

Data are the means \pm SD of four replicates, compared by Duncan's multiple range tests. Values sharing the same lower case letter in a row did not differ

$C K$ sterilized soil-sand mixture without earthworm and mycorrhizae addition, $E$ sterilized soil-sand mixture with earthworm addition, $A M$ sterilized soil-sand mixture with mycorrhizal addition, $A M+E$ sterilized soil-sand mixture with both earthworm and mycorrhizae addition, NS not significant

${ }^{* * *} p<0.001 ;{ }^{* *} p<0.01 ;{ }^{*} p<0.05$

${ }^{1}$ Root colonization rate (\%) : Intensity of the mycorrhizal colonization in the root fragments. Vesicle, Arbuscular, Hyphae frequency (\%) :Vesicle, Arbuscular, Hyphae aboundance in mycorrhizal parts of root fragments. Hyphal length density $\left(\mathrm{g} \mathrm{m}^{-1}\right)$ : The extraradical hyphal abundance in soil

${ }^{a}$ By analysis of variance

mycorrhiza, while urease and cellulose activity were only affected by earthworms.

Compared to the $\mathrm{CK}$ treatment, $\mathrm{AM}$ and $\mathrm{AM}+\mathrm{E}$ significantly decreased available $\mathrm{P}$ and $\mathrm{K}$ (Table $3, p<0.05$ ). Treatment E significantly enhanced ammonium-N content, but decreased soil available $\mathrm{P}$ and $\mathrm{K}$ contents $(p<0.05)$. There was a significant interactive effect of earthworm and AM fungi on available $\mathrm{P}$ and $\mathrm{K}$ contents. Organic $\mathrm{C}$ content was lower $(p<0.05)$ in the AM and $\mathrm{E}$ treatments, but higher $(p<0.01)$ in the AM+E treatment than in the CK treatment (Table 3). The RDA analysis showed that the presence of organisms had a significant influence on organic $\mathrm{C}$ and available N, P, and K contents (Fig. 1a).

The $\mathrm{E}$ treatment significantly increased maize shoot and root biomass compared to the $\mathrm{CK}$ treatment $(p<0.05)$, while AM only significantly improved maize shoot biomass (Table 4). The shoot and root biomass for the AM+E treatment was significantly higher than those of the CK treatment $(p<0.05)$. However, the interaction between earthworm and AM fungi was only significant for the shoot biomass $(p<0.01$; Table 4). Compared to the CK treatment, $\mathrm{E}$ and $\mathrm{AM}+\mathrm{E}$ treatments significantly $(p<0.05)$ increased

Table 2 Urease activity, acid phosphatase activity, and cellulase activity of the soil-sand mixture at the harvest

\begin{tabular}{|c|c|c|c|}
\hline Inoculation treatment & Urease $\left(\mathrm{mg} \mathrm{NH}_{4}^{+}-\mathrm{N} \mathrm{g}^{-1}\right)$ & Acid phosphatase ( $\mu$ g PNP $g^{-1} h^{-1}$ ) & Cellulase $\left(\mu \mathrm{g}\right.$ glucose $\mathrm{g}^{-1} \mathrm{~h}^{-1}$ ) \\
\hline $\mathrm{CK}$ & $16.15 \pm 2.90 \mathrm{c}$ & $24.76 \pm 0.78 \mathrm{c}$ & $97.54 \pm 14.98 b$ \\
\hline $\mathrm{AM}$ & $19.74 \pm 2.79 b c$ & $44.72 \pm 1.25 \mathrm{a}$ & $89.63 \pm 21.26 b$ \\
\hline $\mathrm{E}$ & $22.71 \pm 3.03 b$ & $28.80 \pm 1.27 \mathrm{~b}$ & $184.83 \pm 31.80 \mathrm{a}$ \\
\hline $\mathrm{AM}+\mathrm{E}$ & $28.42 \pm 2.13 \mathrm{a}$ & $42.72 \pm 1.91 \mathrm{a}$ & $220.04 \pm 90.33 \mathrm{a}$ \\
\hline \multicolumn{4}{|l|}{ Significance $^{\mathrm{a}}$ due to } \\
\hline AM inoculation & $* *$ & $* * *$ & NS \\
\hline E inoculation & $* * *$ & NS & $* *$ \\
\hline $\mathrm{AM} * \mathrm{E}$ interaction & NS & $* *$ & NS \\
\hline
\end{tabular}

Data are the means \pm SD of four replicates, compared by Duncan's multiple range tests. Values sharing the same lower case letter in a row did not differ

$C K$ sterilized soil-sand mixture without earthworm and mycorrhizae addition, $E$ sterilized soil-sand mixture with earthworm addition, $A M$ sterilized soil-sand mixture with mycorrhizal addition, $A M+E$ sterilized soil-sand mixture with both earthworm and mycorrhizae addition, $N S$ not significant

${ }^{* * *} p<0.001 ;{ }^{* *} p<0.01 ;{ }^{*} p<0.05$ 
Fig. 1 Independent and interactive action of earthworms and AM fungi on the properties of the sterilized soil-sand mixture (a) and maize nutrient uptake (b) in ordination diagrams from RDA. The coordinate from the first two ordination axes explained $62.6 \%$ and $63.6 \%$ of the variance in $\mathbf{a}$ and $\mathbf{b}$, respectively. The significance (according to Monte Carlo permutation tests) of all canonical axes was $P=0.002$, indicating that the presence of soil organisms had a significant influence on the sterilized soil-sand mixture properties and maize nutrition uptake. $C K$ is the sterilized soil-sand mixture without earthworm and mycorrhizae addition, $E$ is the sterilized soil-sand mixture with earthworm addition, $A M$ is the sterilized soil-sand mixture with mycorrhizal addition, $A M+E$ is the sterilized soil-sand mixture with both earthworm and mycorrhizae addition

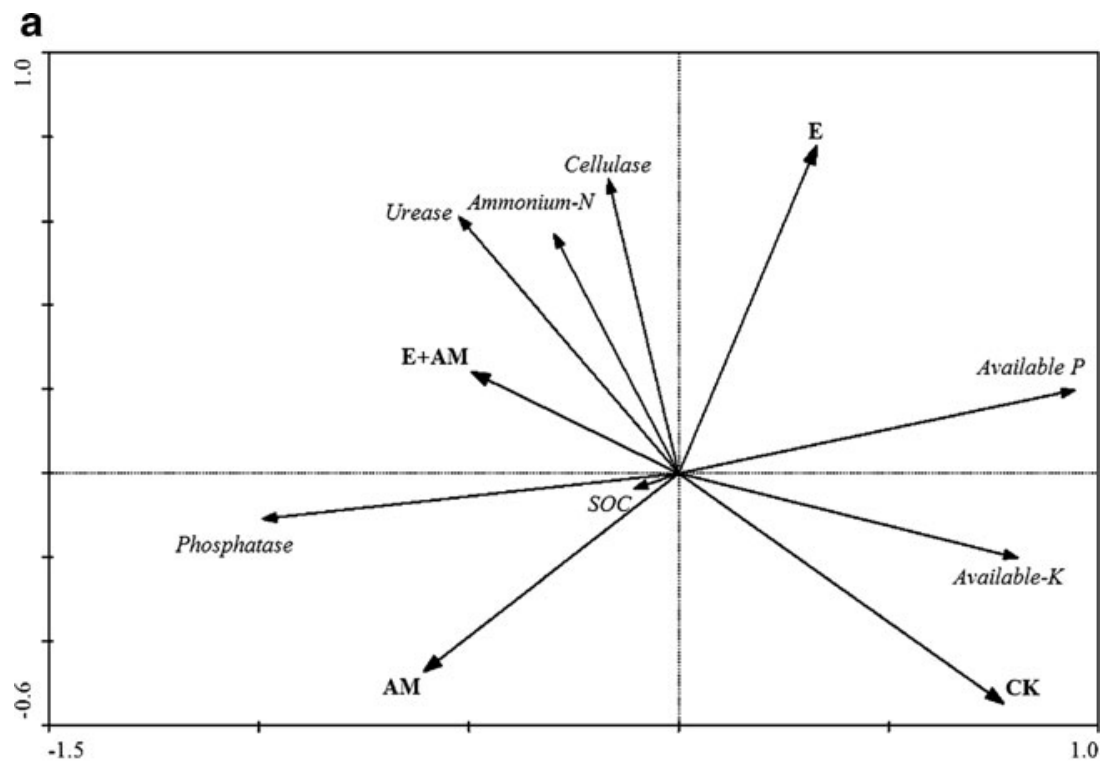

b

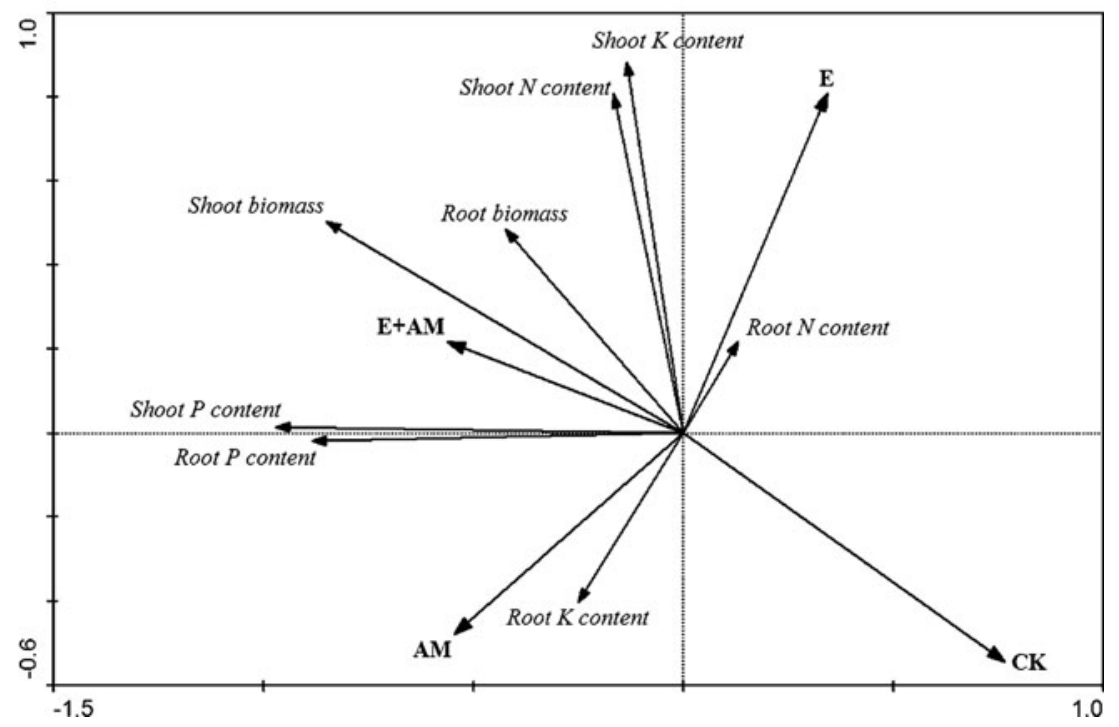

shoot $\mathrm{N}$, $\mathrm{P}$, and $\mathrm{K}$ contents but had no significant effects on root $\mathrm{N}, \mathrm{P}$, and $\mathrm{K}$ contents. The $\mathrm{AM}$ and $\mathrm{AM}+\mathrm{E}$ treatments significantly improved shoot and root $\mathrm{P}$ content compared to the CK treatment $(p<0.01)$. The RDA analysis showed that there was a relationship between organisms (AM fungi inoculated or not inoculated; earthworms added or not added) and maize nutrition uptake (Fig. 1b).

\section{Discussion}

Results of previous studies examining earthworm and mycorrhizal interactions have been inconsistent. Positive (Cheng et al. 2005, 2006; Zarea et al. 2009), negative (Gormsen et al. 2004; Pattinson et al. 1997; Welke and Parkinson 2003), and neutral (Eisenhaller et al. 2009; Ma et al. 2006; Wurst et al. 2004) effects of earthworms on AM root colonization have been reported. Our results suggested that epigeic earthworms increased colonization rate and hyphae frequency on maize roots and HLD in the rhizosphere soil-sand mixture treated with wheat straw. It has been reported that earthworms can produce phytohormones stimulating mycorrhizal infections (Azcón et al. 1978). Unlike endogeic or anecic earthworms, epigeic earthworms live above the surface of soil mineral particles and form little burrows (Edwards and Fletcher 1988; Römbke et al. 2005; Scheu 1987), and this can reduce their negative effect on mycorrhizal colonization (Pattinson et al. 1997; Scheu 2003; Welke and Parkinson 2003). Alternatively, wheat straw may provide substrates to epigeic earthworms, minimizing potential damages to fungal hyphae (Li et al. 2012). All these factors might have contributed to the overall 
Table 3 Organic $\mathrm{C}, \mathrm{NH}_{4}{ }^{+}-\mathrm{N}$, and available $\mathrm{P}$ and $\mathrm{K}$ concentrations of the soil-sand mixture at harvest

\begin{tabular}{|c|c|c|c|c|}
\hline Inoculation treatment & Ammonium- $\mathrm{N}\left(\mathrm{mg} \mathrm{kg}^{-1}\right)$ & Available P (mg kg $\left.{ }^{-1}\right)$ & Available $\mathrm{K}\left(\mathrm{mg} \mathrm{kg}^{-1}\right)$ & SOC $(\%)$ \\
\hline $\mathrm{CK}$ & $4.82 \pm 0.45 b$ & $1.55 \pm 0.10 \mathrm{a}$ & $16.44 \pm 0.28 \mathrm{a}$ & $1.18 \pm 0.02 b$ \\
\hline $\mathrm{AM}$ & $5.16 \pm 0.09 \mathrm{ab}$ & $0.97 \pm 0.05 \mathrm{c}$ & $13.09 \pm 0.25 b$ & $1.12 \pm 0.02 \mathrm{c}$ \\
\hline $\mathrm{E}$ & $5.39 \pm 0.31 \mathrm{a}$ & $1.46 \pm 0.11 \mathrm{~b}$ & $14.47 \pm 0.68 b$ & $1.12 \pm 0.03 \mathrm{c}$ \\
\hline $\mathrm{AM}+\mathrm{E}$ & $5.23 \pm 0.23 \mathrm{ab}$ & $1.12 \pm 0.06 \mathrm{c}$ & $13.69 \pm 0.53 b$ & $1.25 \pm 0.02 \mathrm{a}$ \\
\hline \multicolumn{5}{|l|}{ Significance ${ }^{a}$ due to } \\
\hline AM inoculation & NS & $* * *$ & $* *$ & $*$ \\
\hline E inoculation & $*$ & NS & NS & $*$ \\
\hline $\mathrm{AM} * \mathrm{E}$ interaction & NS & * & $*$ & $* * *$ \\
\hline
\end{tabular}

Data are the means \pm SD of four replicates, compared by Duncan's multiple range tests. Values sharing the same lower case letter in a row did not differ

$C K$ sterilized soil-sand mixture without earthworm and mycorrhizae addition, $E$ sterilized soil-sand mixture with earthworm addition, $A M$ sterilized soil-sand mixture with mycorrhizal addition $A M+E$ sterilized soil-sand mixture with both earthworm and mycorrhizae addition, $N S$ not significant

${ }^{* * *} p<0.001 ;{ }^{* *} p<0.01 ;{ }^{*} p<0.05$

positive impact of epigeic earthworms on the colonization rate and HLD of AM fungi observed in the present study.

Earthworms contribute to enzyme activities of soil through their casts (including surface and underground casts) (Tao et al. 2009). Although, the present enzyme assays do not give valid information on the distribution and comparative importance of reactions mediated by microbes (Nannipieri et al. 2002), soil microbial diversity can also affect enzyme activity
(Nannipieri et al. 2003). It has been reported that AM fungi can increase soil neutral phosphatase and alkaline phosphatase activities by altering the root exudation pattern or fungal exudates (Wang et al. 2006, 2007; Zhang et al. 2011). In the present study, the activity of cellulase, phosphatase, and urease of soil-sand mixture were all significantly increased by earthworms $(p<0.05)$, confirming what has already been reported. (Don et al. 2008; Tiwari et al. 1989; Zhang et al.

Table 4 Mean values of shoot and root biomass (g dry matter wt) and nutrient uptake at harvest

\begin{tabular}{|c|c|c|c|c|c|c|c|c|}
\hline & \multicolumn{4}{|l|}{ Shoot } & \multicolumn{4}{|l|}{ Root } \\
\hline & $\begin{array}{l}\text { Biomass (g/ } \\
\text { plant) }\end{array}$ & $\begin{array}{l}\mathrm{N} \text { content } \\
\text { (mg/plant) }\end{array}$ & $\begin{array}{l}\text { P content } \\
\text { (mg/plant) }\end{array}$ & $\begin{array}{l}\mathrm{K} \text { content } \\
\text { (mg/plant) }\end{array}$ & $\begin{array}{l}\text { Biomass (g/ } \\
\text { plant) }\end{array}$ & $\begin{array}{l}\mathrm{N} \text { content } \\
\text { (mg/plant) }\end{array}$ & $\begin{array}{l}\text { P content } \\
\text { (mg/plant) }\end{array}$ & $\begin{array}{l}\text { K content } \\
\text { (mg/plant) }\end{array}$ \\
\hline $\mathrm{CK}$ & $10.37 \pm 0.14 \mathrm{c}$ & $12.05 \pm 0.32 \mathrm{~b}$ & $0.92 \pm 0.04 \mathrm{c}$ & $44.61 \pm 2.41 \mathrm{~b}$ & $4.93 \pm 0.30 \mathrm{~b}$ & $4.22 \pm 0.42 \mathrm{a}$ & $0.34 \pm 0.02 b$ & $5.32 \pm 1.39 \mathrm{a}$ \\
\hline $\mathrm{AM}$ & $13.29 \pm 0.17 b$ & $11.87 \pm 0.41 b$ & $1.74 \pm 0.05 \mathrm{a}$ & $45.84 \pm 2.12 b$ & $5.39 \pm 0.22 \mathrm{ab}$ & $4.06 \pm 0.13 \mathrm{a}$ & $0.55 \pm 0.04 \mathrm{a}$ & $5.84 \pm 0.12 \mathrm{a}$ \\
\hline $\mathrm{E}$ & $13.03 \pm 0.26 b$ & $14.24 \pm 0.582 \mathrm{a}$ & $1.17 \pm 0.05 b$ & $52.42 \pm 2.24 \mathrm{a}$ & $5.57 \pm 0.05 \mathrm{a}$ & $4.25 \pm 0.19 \mathrm{a}$ & $0.40 \pm 0.03 b$ & $4.80 \pm 0.52 \mathrm{a}$ \\
\hline $\mathrm{AM}+\mathrm{E}$ & $14.33 \pm 0.21 \mathrm{a}$ & $14.50 \pm 0.18 \mathrm{a}$ & $1.86 \pm 0.07 \mathrm{a}$ & $50.19 \pm 1.95 \mathrm{a}$ & $5.62 \pm 0.08 \mathrm{a}$ & $4.27 \pm 0.25 \mathrm{a}$ & $0.56 \pm 0.03 \mathrm{a}$ & $5.30 \pm 0.63 \mathrm{a}$ \\
\hline \multicolumn{9}{|c|}{ Significance $^{\mathrm{a}}$ due to } \\
\hline $\mathrm{AM}$ & inoculation & $* * *$ & NS & $* * *$ & NS & NS & NS & $* * *$ \\
\hline \multicolumn{9}{|l|}{ NS } \\
\hline $\mathrm{E}$ & inoculation & $* * *$ & $* * *$ & $* *$ & $* * *$ & $*$ & NS & NS \\
\hline \multicolumn{9}{|l|}{ NS } \\
\hline $\begin{array}{l}\mathrm{AM} * \mathrm{E} \\
\text { interaction }\end{array}$ & $* *$ & NS & NS & NS & NS & NS & NS & NS \\
\hline
\end{tabular}

Data are the means \pm SD of four replicates, compared by Duncan's multiple range tests. Values sharing the same lower case letter in a row did not differ

$C K$ sterilized soil-sand mixture without earthworm and mycorrhizae addition, $E$ sterilized soil-sand mixture with earthworm addition, $A M$ sterilized soil-sand mixture with mycorrhizal addition, $A M+E$ sterilized soil-sand mixture with both earthworm and mycorrhizae addition, $N S$ not significant

${ }^{* * *} p<0.001 ;{ }^{* *} p<0.01 ;{ }^{*} p<0.05$ 
2000). In addition to releasing enzymes with casts, earthworms can affect enzyme activity of the soil by stimulating soil microbial activity (Zhang et al. 2000). Stimulation of ureolytic microorganisms, and thus increase in urease activity, can also occur in soil (Caravaca et al. 2003). However, more detailed investigations are needed to understand the interactive influence between microbial diversity and earthworm on soil enzyme activities.

Enzyme activity can be related to the availability of nutrients in soil (He et al. 2010). For example, urease activity hydrolyzes urea $\mathrm{N}$ to $\mathrm{NH}_{4}{ }^{+}-\mathrm{N}$ (Don et al. 2008). Indeed, we have observed a positive and a significant $(p<0.05)$ correlation between urease activity and ammonium-N content $(p<0.05)$ in the present study. However, the activity of acid phosphatase was negatively correlated with available $\mathrm{P}$ and $\mathrm{K}$ $(p<0.001)$. Probably earthworms decreased available $\mathrm{P}$, thus stimulating the activity of acid phosphatase. AM fungi also significantly increased the activity of acid phosphatase with the consequent decrease in available $\mathrm{P}$ and $\mathrm{K}$ concentrations. Earthworms and AM fungi interacted in their effects on acid phosphatase activity.

The observed reduction in organic $\mathrm{C}$ content with $\mathrm{AM}$ possibly resulted from hyphal growth of $G$. intraradices in response to specific compounds such as 3,4,5-substituted benzyl structures. These compounds have been reported to enhance soil organic matter decomposition and decrease organic C content (Gryndler et al. 2009). The content of organic $\mathrm{C}$ was reduced in the $\mathrm{E}$ treatment. Probably the digestion activity of earthworms increased mineralization and humification of organic matter (Lavelle 1988). However, the effects of earthworms on organic matter transformations are not limited by the short and transit gut activities because the earthworm casts can prolong microbial activities, thus affecting soil organic matter transformation (Lavelle 1988).

Earthworms and arbuscular mycorrhiza fungi (AMF) are important organisms of the rhizosphere soil. AM fungi form prominent symbioses with roots, increasing their potential to mobilize nutrients, particularly $\mathrm{P}$ (Bago et al. 2000; Artursson et al. 2006), which can affect growth and physiology of most plants (Jeffries et al. 2003; Smith and Read 2008). Although the propagules in the native soil were lower than those in mycorrhizal inocula, the indigenous AM fungi of soil could colonize the host plants in the nonmycorrhized treatments (Wang et al. 2006; Zarea et al. 2009). In order to avoid the effects of the indigenous AM fungi and increase soil porosity and permeability, we used the sterilized soil-sand mixture (Hayman and Tavares 1985). Compared to the CK treatment, the AM treatment significantly increased maize shoot and root $\mathrm{P}$ content as well as shoot biomass. Similarly, the E treatment also increased biomass of maize and shoot $\mathrm{N}$ and $\mathrm{P}$ contents. These results are consistent with reports that earthworms influence plant growth by altering the spatiotemporal availability of P and N contents (Edwards 2004; Eisenhauer and Scheu 2008; Laossi et al. 2010). In addition, shoot K content was increased in the $\mathrm{E}$ treatment, and the activities of soil cellulase showed a significant $(p<0.05)$ positive correlation with the shoot $\mathrm{K}$ content.

Earthworms and AM fungi function as different nutrient providers and create distinct niches for plants (Wurst et al. 2010). They can increase plant nutrient availability in soil and synergically can increase plant nutrient uptake (Eisenhauer et al. 2009). In the present study, shoot and root biomass and their $\mathrm{N}$ and $\mathrm{P}$ contents were increased in the $\mathrm{AM}+\mathrm{E}$ treatment compared to the CK treatment. In addition, earthworms and $\mathrm{AM}$ fungi increased maize shoot biomass in an interactive way. Results suggest that earthworms and AM fungi can enhance the availability of $\mathrm{N}, \mathrm{P}$, and $\mathrm{K}$ contents in the soilsand mixture and their uptake by the plant, resulting in an improved plant growth (Bardgett 2005; Li et al. 2012; Wurst et al. 2004).

\section{Conclusion}

Epigeic earthworms (E. fetida) increased maize shoot and root biomass by affecting the activities of urease, acid phosphatase, and cellulase and increased availability of N, P, and K contents in the sterilized soil-sand mixture and their uptake by maize. AM fungi ( $G$. intraradices) increased the maize shoot biomass by enhancing acid phosphatase activity and shoot and root $\mathrm{P}$ content. AM fungi and earthworm interactively increased maize shoot and root biomass probably through their effects on enzyme activities and on availability of $\mathrm{N}, \mathrm{P}$, and $\mathrm{K}$ in the sterilized soil-sand mixture, which complementarily improved maize nutrient uptake and growth. This research shed light on the possibility to improve plant nutrient uptake by regulating biology, which could explore the potential for soil biological fertility in the sustainable agricultural system.

Acknowledgments We are grateful to Dr. Zhiguo Wu from University of Pennsylvania for comments on the manuscript. This work was funded by the Special Scientific Fund for Non-profit Public Industry (MOA, 201103003), National Natural Science Foundation of China (Project 31172037), Innovative Group Grant of NSFC (31121062), and Scientific Research Foundation at China Agricultural University (Project 2010JS112).

\section{References}

Aira M, Monroy F, Domínguez J (2005) Ageing effects on nitrogen dynamics and enzyme activities in casts of Apprrectodea caliginosa (Lumbricidae). Pedobiologia 49:467-473

Artursson V, Finlay RD, Jansson JK (2006) Interactions between arbuscular mycorrhizal fungi and bacteria and their potential for stimulating plant growth. Environ Microbiol 8:1-10

Axmann H, Sebastianelli A, Arrillaga JL (1990) Sample preparation techniques of biological material for isotope analysis. In: 
Hardarson G (ed) Use of nuclear techniques in studies of soilplant relationship. International Atomic Energy Agency, Viena, pp 41-53

Azcón R, Azcon-Aguilar C, Barea JM (1978) Effect of plant hormones present in bacterial cultures on the formation and responses to VA endomycorrhiza. New Phytol 80:359-364

Bago B, PfefferP E, Shachar-Hill Y (2000) Carbon metabolism and transport in arbuscular mycorrhizas. Plant Physiol 124:924-957

Bardgett RD (2005) The biology of soil: a community and ecosystem approach. Oxford University Press, Oxford, 69-85

Calvet C, Pera J, Barea JM (1993) Growth response of marigold (Tagetes erecta L.) to inoculation with Glomus mosseae, Trichoderma aureoviridae and Pythium ultimum in a peat-perlite mixture. Plant Soil 148:1-6

Caravaca F, Alguacil MM, Figueroa D, Barea JM, Roldan A (2003) Re-establishment of Retama sphaerocarpa as a target species for reclamation of soil physical and biological properties in a semiarid Mediterranean area. Forest Ecol Manage 182:49-58

Caravaca F, Alguacil MM, Azcón R, Díaz G, Roldán A (2004) Comparing the effectiveness of mycorrhizal inoculation and amendment with sugar beet, rock phosphate and Aspergillus niger to enhance field performance of the leguminous shrub Dorycnium pentaphyllum L. Appl Soil Ecol 25:169-180

Cheng J-M, Yu X-Z, Wong M-H (2005) Roles of earthworm-mycorrhiza interactions on phytoremediation of $\mathrm{Cd}$ contaminated soil. Aata Ecologica Sinica 25:1256-1263

Cheng J-M, Yu X-Z, Wong M-H (2006) Effect of earthworm-mycorrhiza interaction on available nutrients and ryegrass growth in $\mathrm{Cd}$ contaminated soil. J Agro-Environ Sci 25:685-689

Dilly O, Irmler U (1998) Succession in the food web during the decomposition of leaf litter in a black alder (Alnus glutinosa (Gaertn.) L.) forest. Pedobioligia 42:109-123

Don A, Steinberg B, Schöning I, Pritsch K, Joschko M, Gleixner G, Schulze E-D (2008) Organic carbon sequestration in earthworm burrows. Soil Biol Biochem 40:1803-1812

Edwards CA (2004) Earthworm ecology. CRC, Boca Raton, p 441

Edwards CA, Fletcher KE (1988) Interactions between earthworms and micro-organisms in organic-matter breakdown. Agr Ecosyst Environ 24:235-247

Eisenhauer N, Scheu S (2008) Earthworms as drivers of the competition between grasses and legumes. Soil Biol Biochem 40:2650 2659

Eisenhauer N, Stephan K, Alexander CWS, Renker C, Buscot F, Scheu S (2009) Impacts of earthworms and arbuscular mycorrhizal fungi (Glomus intraradices) on plant performance are not interrelated. Soil Biol Biochem 3:561-567

Gormsen D, Olsson PA, Hedlund K (2004) The influence of collembolans and earthworms on AM fungal. Appl Soil Ecol 27:211-220

Gryndler M, Hrselova H, Cajthaml T, Havrankova M, Rezacova V, Gryndlerova H, Larsen J (2009) Influence of soil organic matter decomposition on arbuscular mycorrhizal fungi in terms of asymbiotic hyphal growth and root colonization. Mycorrhiza 19:255266

Hayman DS, Tavares M (1985) Plant growth responses to vesiculararbuscular mycorrhiza. XV. Influence of soil $\mathrm{pH}$ on the symbiotic efficiency of different endophytes. New Phytol 100:367-377

He X-L, Li Y-P, Zhao L-L (2010) Dynamics of arbuscular mycorrhizal fungi and glomalin in the rhizosphere of Artemisia ordosica Krasch. in Mu Us Sandland, China. Soil Biol Biochem 42:1313-1319

Jakobsen I, Abbott LK, Robson AD (1992) External hyphae of vesicular-arbuscular mycorrhizal fungi associated with Trifolium subterraneum L. 1. Spread of hyphae and phosphorus inflow into roots. New Phytol 120:371-380

Jeffries P, Gianinazz S, Perotto S, Turnau K, Barea JM (2003) The contribution of arbuscular mycorrhizal fungi in sustainable maintenance of plant health and soil fertility. Biol Fert Soils 37:1-16

Jones JJ, Case VW (1990) Sampling, handling, and analyzing plant tissue samples. Samples. In: Westerman R (ed) Soil testing and plant analysis, vol 3, SSSA Book Series. Soil Science Society of America, Madison, pp 389-427

Kandeler E, Gerber H (1988) Short-term assay of soil urease activity using colorimetric determination of ammonium. Biol Fertil Soils 6:68-72

Keeney DR, Nelson DW (1982) Nitrogen-inorganic forms. In: Page AL (ed) Methods of soil analysis. Part 1, vol 9, 2nd edn, Agron. Monogr. ASA and SSSA, Madison, pp 643-698

Laossi KR, Ginot A, Noguera DC, Blouin M, Barot S (2010) Earthworm effects on plant growth do not necessarily decrease with soil fertility. Plant Soil 328:109-118

Lavelle PI (1988) Earthworm activities and the soil system. Biol Fertil Soils 6:237-251

Li H, Li X-L, Dou Z-X, Zhang J-L, Wang C (2012) Earthworm (Aporrectodea trapezoides)-mycorrhiza (Glomus intraradices) interaction and nitrogen and phosphorus uptake by maize. Biol Fertil Soils 48:75-85

Ma Y, Dickinson NM, Wong M-H (2006) Beneficial effect of earthworms and arbuscular mycorrhizal fungi on establishment of leguminous trees on $\mathrm{Pb} / \mathrm{Zn}$ mine tailings. Soil Biol Biochem 38:1403-1412

Mandels M, Andreotti R, Roche C (1976) Measurement of saccharifying cellulase. Biotechnol Bioeng 6:21-34

Mar Vázquez M, César S, Azcón R, Barea JM (2000) Interactions between arbuscular mycorrhizal fungi and other microbial inoculants (Azospirillum, Pseudomonas, Trichoderma) and their effects on microbial population and enzyme activities in the rhizosphere of maize plants. Appl Soil Ecol 15:261-272

McGonigle TP, Miller MH, Evans DG, Fairchild GL, Swan JA (1990) A new method which gives an objective-measure of colonization of roots by vesicular arbuscular mycorrhizal fungi. New Phytol 115:495-501

McLatchey GP, Reddy KR (1998) Regulation of organic matter decomposition and nutrient release in a wetland soil. J Environ Qual 27:1268-1274

Metson AJ (1956) Methods of chemical analysis for soil survey samples. NZ Soil Bureau Bull. No. 12

Miller GL (1969) Use of dinitrosalicylic acid reagent for determination of reducing sugar. Anal Chem 31:426-428

Milleret R, Renée-Claire LB, Jean-Michel G (2009) Root, mycorrhiza and earthworm interactions: their effects on soil structuring processes, plant and soil nutrient concentrations and plant biomass. Plant Soil 316:1-12

Murphy J, Riley JP (1962) A modified single solution method for determination of phosphate in natural waters. Anal Chim Acta 27:31-36

Nannipieri P, Kandeler E, Ruggiero P (2002) Enzyme activities and microbiological and biochemical processes in soil. In: Burns RG, Dick RP (eds) Enzymes in the environment. Activity, ecology and applications. Marcel Dekker, New York, pp 1-33

Nannipieri P, Ascher J, Ceccherini MT, Landi L, Pietramellara G, Renella G (2003) Microbial diversity and soil functions. Eur J Soil Sci 54:655-670

Newman EI (1966) A method of estimating total length of root in a sample. J Appl Ecol 3:139-145

Olsen SR, Cole CV, Watanabe FS, Dean LA (1954) Estimation of available phosphorous in soils by extraction with sodium bicarbonate. USDA Circular 939:1-8

Ortiz-Ceballos AI, Pena-Cabriales JJ, Fragoso C, Brown GG (2007) Mycorrhizal colonization and nitrogen uptake by maize: combined effect of tropical earthworms and velvetbean mulch. Biol Fert Soils 44:181-186 
Parthasarathi K, Ranganathan LS (2000) Aging effect on enzyme activities in pressmud vermicasts of Lampito mauritii (Kinberg) and Eudrilus eugeniae (Kinberg). Biol Fertil Soils 30:347-350

Partsch S, Milcu A, Scheu S (2006) Decomposers (Lumbricidae, Collembola) affect plant performance in model grasslands of different diversity. Ecology 87:2548-2558

Pattinson GS, Smith SE, Doube BM (1997) Earthworm Aporrectodea trapezoides had no effect on the dispersal of a vesicular-arbuscular mycorrhizal fungi, Glomus intraradices. Soil Biol Biochem 29:1079-1088

Römbke J, Jänsch S, Didden W (2005) The use of earthworms in ecological soil classification and assessment concepts. Ecotoxicol Environ Saf 62:266-277

Scheu S (1987) The role of substrate feeding earthworms (Lumbricidae) for bioturbation in a beechwood soil. Oecologia 72:192-196

Scheu S (2003) Effects of earthworms on plant growth: patterns and perspectives. Pedobiologia 47:846-856

Six J, Feller C, Denef K, Ogle SM, Sa JCD, Albrecht A (2002) Soil organic matter, biota and aggregation in temperate and tropical soils-effects of no-tillage. Agronomie 22:755-775

Smith SE, Read DJ (2008) Mycorrhizal symbiosis. Academic Press, San Diego, 1-20

Tabatabai MA (1982) Soil enzymes. In: Page AL, Miller RH, Keeney DR (eds) Methods of soil analysis, part 2. American Society of Agronomy, Madison, pp 903-947

Tao J, Griffiths B, Zhang S, Chen X, Liu M, Hu F, Li H-X (2009) Effects of earthworms on soil enzyme activity in an organic residue amended rice-wheat rotation agro-ecosystem. Appl Soil Ecol 42:221-226

Tiwari SC, Tiwari BK, Mishra RR (1989) Microbial populations, enzyme activities and nitrogen-phosphorus-potassium enrichment in earthworm casts and in the surrounding soil of a pineapple plantation. Biol Fertil Soils 8:178-182

Tuffen F, Eason WR, Scullion J (2002) The effect of earthworms and arbuscular mycorrhizal fungi on growth of and ${ }^{32} \mathrm{P}$ transfer between Allium porrum plants. Soil Biol Biochem 34:1027-1036

Walkley A (1947) A critical examination of a rapid method for determining organic carbon in soils: effect of variations in digestion conditions and of inorganic soil constituents. Soil Sci 63:251-264

Wang F-Y, Lin X-G, Yi R, Wu L-H (2006) Effects of arbuscular mycorrhizal inoculation on the growth of Elsholtzia splendens and Zea mays and the activities of phosphatase and urease in a multi-metal-contaminated soil under unsterilized conditions. Appl Soil Ecol 31:110-119

Wang M-Y, Xia R-X, Wu Q-S, Liu J-H, Hu L-M (2007) Influence of arbuscular mycorrhizal fungi on microbes and enzymes of soils from different cultivated densities of red clover. Ann Microbiol 57:1-7

Welke SE, Parkinson D (2003) Effect of Aporrectodea trapezoides activity on seedling growth of Pseudotsuga menziesii, nutrient dynamics and microbial activity in different soils. Forest Ecol Manag 173:169-186

Wurst S, Dugassa-Gobena D, Langel R, Bonkoski M, Scheu S (2004) Combined effects of earthworms and vesicular-arbuscular mycorrhizas on plant and aphid performance. New Phytol 163:169-176

Wurst S, Gebhardt K, Rillig MC (2010) Independent effects of arbuscular mycorrhiza and earthworms on plant diversity and newcomer plant establishment. J Veg Sci 22:1021-1030

Zarea MJ, Ghalavand A, Goltapeh EM (2009) Effects of mixed cropping, earthworms (Pheretima sp.), and arbuscular mycorrhizal fungi (Glomus mosseae) on plant yield, mycorrhizal colonization rate, soil microbial biomass, and nitrogenase activity of free-living rhizosphere bacteria. Pedobiologia 4:223235

Zhang B-G, Li G-T, Shen T-S, Wang J-K, Sun Z (2000) Changes in microbial biomass $\mathrm{C}, \mathrm{N}$, and $\mathrm{P}$ and enzyme activities in soil incubated with the earthworms Metaphire guillelmi or Eisenia fetida. Soil Biol Biochem 32:2055-2062

Zhang L, Zhang J, Christie P, Li X (2008) Pre-inoculation with arbuscular mycorrhizal fungi suppresses root knot nematode (Meloidogyne incognita) on cucumber (Cucumis sativus). Biol Fertil Soils 45:205-211

Zhang H, Wu X, Li G, Qin P (2011) Interactions between arbuscular mycorrhizal fungi and phosphate-solubilizing fungus (Mortierella $\mathrm{sp}$.) and their effects on Kostelelzkya virginica growth and enzyme activities of rhizosphere and bulk soils at different salinities. Biol Fertil Soils 47:543-554 